\title{
An Account on a Social Network Site as a Site of Memory. Memory in the Internet Fake, Like and Hate. A New Expression of Polish Patriotism?
}

\section{Introduction}

Progress in the sphere of new technologies strongly and unquestionably influences social transformations, driving and directing them. Although the above statement would seem to be a truism, it should be recalled as the first step in the consideration of one of the dynamically developing phenomena within the Internet space, namely the commemorating the past. It takes place through various websites, but it is worth paying special attention to one of their types - social media portals. Various social networks are built through such websites, and as a result of their narratives, their accounts must be treated as sites of memory which, being a reflection of the ongoing transformations in the societies of the modern world, are at the same time their source. The overriding premise of this text is, therefore, the reflection on the phenomena of fake (Pol. fejk), like (Pol. lajk) and hate (Pol. hejt) ${ }^{1}$ present in the narratives of social media, in view of the expression of patriotism, which can be read from them. More importantly, the article explores the case of Poland - Polish patriotism and Polish patriotic accounts that have appeared on Facebook (the most popular social networking site in Poland) (Zimowska, 2018). In this way, the purpose of the text became not only to answer the question of what image of Polish patriotism is offered by the Internet fake, like and hate, but also what their causes and consequences are for the Polish community.

\section{Memory and site of memory}

Human memory should be regarded as the ability to record, store and reproduce sensory experiences, associations and various types of information. It is obvious, there-

1 The Polish word fejk comes from the English word fake (i.e. a counterfeit, imitation, forgery) and means forgery on the Internet. The widely popular among Polish Internet users word hejt comes from the English word hate and refers to hateful statements on the web, criticizing an event, someone's attitude or a given person. The Polish word lajk, in turn, (Eng. like) refers to approval of a specific web content (Niepytalska-Osiecka, 2014:343-345).

\footnotetext{
* Correspondence address: Instytut Nauk o Polityce i Administracji, Uniwersytet Zielonogórski, al. Wojska Polskiego 69, 65-762 Zielona Góra, Polska, e-mail: anna.ratkemajewska@gmail.com.
} 
fore, that knowing and remembering the course of an event by a human being can take place as a result of their personal experience. This is not, however, the only method of constructing the range of human memory, because - apart from personal experience there is also the other way of developing memory content: namely participation in a given culture, providing information about past events. Knowing the past is, therefore, the result of both personal experiences and intracultural phenomena taking place. In other words, human memory can create, on the one hand - people's experiences and, on the other - stories about the past existing in the culture of which a given person is a part and within which they function. Such stories of the past, placed in the cultural context, are historical narratives of a particularly significant character to understand the problem of memory. One of their basic features is that they do not reflect the past itself, but interpretations of the past (images existing in the culture and concerning past events). Why interpretations, and not faithful renditions of facts? The reason is that the record of a specific event cannot be fixed in the memory of a human being in a form comparable to a film recording. The memorized contents are first of all selected, and while in the process of reconstructing, they are enriched with knowledge, views and emotions. That is why every historical narrative - i.e. a story about the past - is an interpretation, an image. It is important that among such stories about past events, one should mention both academic and popular science works as well as media and journalistic messages, witnesses' accounts, art products, myths, symbols and contents of politics of memory (by means of which state authorities determine the constituent parts of collective memory in order to protect the continuity of the community and to achieve benefits in the field of current politics). Stories of the past are, therefore, also sites of memory, worth devoting more attention to in view of the subject undertaken (Marszałek-Kawa, Ratke-Majewska, Wawrzyński, 2016: 49-50; Maruszewski, 2001: 79, 117-118; Ratke-Majewska, 2017: 45-46; Ratke-Majewska, Marszałek-Kawa, 2017: 42-43; Schacter 2003: 22; Tokarz 2005: 4-11; see also: Assmann, 2008).

The researcher who is considered to be the initiator of reflections on the issues of sites of memory (lieux de memoire) was the French historian Pierre Nora - and the issue was first discussed in his works in the 1970s. From the descriptions he presented, it can be concluded that he, in fact, perceived the site of memory as the site in the literal meaning of the word, where communities (the nation, family, ethnic group or party) store their memories or the one which is collectively considered as an inseparable element of their personality. Within the group of lieux de memoire, he distinguished topographical places (archives, libraries, museums), monumental places (architecture, cemeteries, monuments), symbolic places (pilgrimages, anniversaries, commemorations) and functional places (autobiographies, textbooks, associations). It should be pointed out that the understanding of the very term of the site of memory within Pierre Nora's analyses has widened over time. In the author's initial considerations of the subject, lieux de memoire focused on material places, in later works (from the 1980s) the 
researcher considered the aspect of immateriality in their perception. This approach treating the materiality of the site of memory as a secondary attribute - was not isolated in the academic field. Hence, one of the ways to understand the site of memory is the one in which the key attribute of lieu de memoire is its ability to store and protect the memory of past times, not materiality. The site of memory in this approach is first of all the property of the community which stores its essential values (including standards, models and ideas). In the same way, a material museum, archive or monument, as well as intangible signs and symbols contained in language, art, poetry or legal regulations, may be considered as lieu de memoire (Minta-Tworzowska, 2013: 36; Nora, 2001: 37-43; Ratke-Majewska, 2018: 269-271; Szpociński, 2008: 11-12, 14-15; Traba, 2006: 31; see also: Delaperrière 2013: 49-61).

Taking the above-mentioned findings into account, it should be stated that the developing interpretations of the understanding of the site of memory have expanded the catalogue of forms that may be recognized as such. An expanding interpretation of the term lieux de memoire on the one hand, and technological progress on the other, meant that among the sites of memory - i.e. places that recall the past and constitute a symbolic element of the heritage of memory of every community that can be used as a tool for state memory policy (see: Ratke-Majewska, 2018: 269; Szpociński, 2008: 11-20) those that are virtual places should also be taken into account nowadays. To such virtual places, accounts on social networks should be included.

In order to get an answer to the question of what image of Polish patriotism is presented by the Internet fake, like and hate and what its causes and consequences are for the Polish community, the author of this text presented the results of her own research. The research involved the content analysis of the memory narratives constructed by users of Polish patriotic accounts operating on Facebook. Such a research method allowed her to identify specific elements and narrative patterns in order to answer the posed research problem. The results of the analyses carried out and conclusions referring to the issue of Polish patriotism presented in the online space are presented below. It should be noted, at this stage, that considerations on shaping the content of memory on the Internet, reflections on the meaning of virtual sites of memory and analyses regarding hate speech have already begun in many academic fields. This subject - in numerous approaches - has been tackled mainly from the perspective of sociology, psychology, linguistics, philosophy, as well as political science. The multiplicity of disciplines listed does not mean, however, that the constituent topics behind the issue have been exhausted. On the contrary, the dynamics of changes in the very area encourage continuing research, including consideration of the problem of the image of Polish patriotism in the internet fake, like and hate, which has not been explored to date (see among others: Bartoletti, 2011: 82-111; Caygill, 1999: 1-11; García-Gavilanes, Mollgaard, Tsvetkova, Yasseri, 2017: 1-7; Ginosar, Konovalov, 2015: 368-383; Gündüz, Erdem, 2017: 1929; Gündüz, 2017: 85-92; Müller, Schwarz, 2018). 


\section{Memory and expression of Polish patriotism in the Internet fake, like and hate - findings}

The research carried out by the author of the presented article was concerned with Polish Facebook accounts on the subject of patriotism, focused on both formal issues (number of webpages and their popularity), as well as substantive issues (issues dealt with within a given site, threads raised and users' opinions). The results of the research revealed that there were several hundred Polish accounts on Facebook describing themselves as patriotic. Most of them were created over the last few years (mainly after 2012) and enjoy popularity from several to several hundred thousand people (based on the number of followers or likes).

The thematic scope of the discussed websites is moderately diverse, and the threads are multiplied, which makes it possible to clearly define the common area of interest and the problems under consideration within the majority of the webpages characterized. The basic problems that a given account is devoted to are usually expressed in the form of the site's motto (such as: "God, Honour, Fatherland"). Sometimes the subject matter is reflected by all kinds of adages, slogans or fragments of patriotic songs. As for the advocated values, these are most often revealed in the contents of the posts that are published. Among the most significant are: national pride, memory of selected heroes and events, family, fidelity to the Catholic Church in Poland, as well as anti-leftist, anti-laicism and anti-communism worldviews. On sites with the more radical tone, there are also threads expressing anti-Russian and anti-German attitudes (both in the context of Polish history, as well as current politics), anti-French ones (often in the form of mockery of the French society and its tolerance of other nations or religious diversity that contribute to security breaches), calls for retaliation (payment for harms done), clear political declarations (pro-Law and Justice [Pol. Prawo i Sprawiedliwość] and anti-Civic Platform [Pol. Platforma Obywatelska]), expressions of approval of the undertaken direction of Polish economic development, "stop abortion" and "stop gender" slogans, as well as militarism. It can be seen, therefore, that modern themes appear alongside historical ones.

Among the narrations of memory conducted as part of Polish accounts identifying themselves as patriotic, many threads appear on Facebook, but they can be grouped into two main themes of stories about the past. The first of these is the memory of heroes. It should be noted that among the heroic figures and historical formations, the leading ones are the Cursed Soldiers, including Józef Kuraś, Danuta Siedzikówna “Inka”, Witold Pilecki, Marian Bernaciak, pseudonym "Orlik", Zdzisław Broński pseudonym "Uskok”, and as an organization - the National Armed Forces (Pol. Narodowe Siły Zbrojne). Often, the figures of Władysław Raginis, the defence commander of Wizna, as well as Józef Piłsudski and Roman Dmowski are also evoked. What is more, an important place in the memory narratives is occupied by hussars. 
The second thematic group in the area of stories about the past are narratives that arouse the memory of the tragic and/or essential events for the Polish nation. Among the most frequent events of this type are the enactment of the $3^{\text {rd }}$ May Constitution, the children's strike in Września, the Warsaw Uprising, the battle of Monte Cassino, the Katyń massacre and the Volhynia slaughter.

It should be added that the narratives undertaken on the analyzed webpages fit into the category of the founding myth and the heroic myth ${ }^{2}$. The founding myth of the democratic Polish state manifests itself in its two expressions. The first one is the myth of the unwavering armed struggle (the fight against an invader, struggle against an occupier and oppressor for freedom and independence), the second - the myth of a long tradition of democracy and power (there are sporadic references to the theory of the Great Empire of Lechites) ${ }^{3}$. The heroic myth is invoked above all by the Cursed Soldiers (as those who fought both the German and Soviet occupiers), as well as through references to hussars, presented as a victorious, powerful and universally respected formation.

The analysis of Polish accounts defining themselves as patriotic on Facebook also allowed the author to draw attention to another important issue, answering the question of what traits in the meaning of the narratives of the considered webpages should a Pole and a Pole-patriot possess. The most characteristic, distinct set of features created by the users of the websites surveyed can be summarized by the statement: every Pole should be a patriot, and every patriot should adhere to the values expressed in the words "God, Honour, Fatherland". In other words, a Pole - in view of the content of the discussed accounts - must be devoted to the Homeland, be proud of it, and be faithful to its values, should also devote themselves to their family and be a practicing Catholic, must be characterized by courage and honour, as well as be rebellious and rejecting foreign influences.

The range of symbols that are used by patriotic accounts on Facebook should not be neglected. First and foremost, their users use national colours and symbols, with the very frequent motif of the national emblem and state flag. An almost integral element is also the Fighting Poland Sign (Kotwica), which is invoked not only in the created images, but also on the patriot clothing that is often promoted on numerous occasions.

2 A myth is a narrative form used to form traditional knowledge, a story about events that are crucial for the community. A special place in the process of creating and maintaining the existence of a national community is occupied by the two types of myths: the founding myth and the heroic one. The former of the listed ones - also called the myth of the origin - defines the mythical lineage of a nation, the latter - the myth of a hero, saviour, healer whose life and represented values appear to be a pattern of conduct for the whole society (see: Campbell, 1997: 19, 34, 39; Czeremski, Sadowski, 2012: 13, 16-17; Kołakowski, 2005: 9, 15-22; Siewierska-Chmaj, 2016: 19, 39-55, 132-167; Waniek, 2011: 9-45).

3 Theories expressing faith in the Great Empire of Lechites are based on the belief that there existed a pre-Christian Lechic power (an early-Polish empire), whose fates were forgotten as a result of the activity of hostile forces such as the Vatican, Germans or Jews. People who advocate this version of history - pseudohistorical and alternative - are called Turboslavs (see: Leszkowicz, 2017). 
The last issue that should be addressed in the course of the analysis was the issue of the frequency of individual reactions to the contents appearing in the context of patriotic accounts. Due to the fact that most of their users identify themselves with the narratives presented by the websites, the most common response is like, usually expressed with the "like it" or "super" button. Less frequent are comments expressing support, often simultaneously voicing anti-leftist attitudes or reluctance to non-state media. Sometimes there appears hate, mostly in mockery or - less often - as a voice in a discussion. It should be emphasized here that both the element of the considerations referred to in this paragraph and the results of the research presented above allowed to formulate conclusions, which are included in the following summary $y^{4}$.

\section{Conclusions}

The analysis of the sites defining themselves as patriotic clearly demonstrated that patriotism expressed in fake, like and hate focuses primarily on slogans, adages, symbols, as well as stirring emotions through images - and it is not focused on discussion (as its aim is not to stimulate discussion, but to encourage support). It does not focus on the pursuit of honest historical knowledge or deeper reflection on the past. It is patriotism based on short-lived excitement (mainly fleeting emotions), where a zealous memory of an event is accompanied by a lack of knowledge about it (see: Bauman, 2000: 92-120; Szpociński, 2011: 13-15).

What is more, the slogans and adages appearing on the pages that claim to be patriotic evoke hate, in addition to the support expressed above all else by like. The impression is created that only extremes exist - with people who regard themselves as patriots representing the entire worldview background, which is placed on patriotic sites, on the one hand, and people completely and uncompromisingly against them, on the other. Those who are 'against' - according to the analyzed websites - are not considered to be patriots, but often perceived as enemies of Poland, traitors called "leftists", or "ubeks" (i.e. security police workers). Views that could be regarded as centrist in this matter are not evident. In this way, the impression is created that there is only one 'real' expression (or basically - considering itself 'real') of patriotism, rejecting other views. Patriotism expressed in fake, like and hate is, therefore, an exclusive patriotism - involving the exclusion from the nation all those who do not meet some criterion - and defensive, which is one that seeks to separate from all others who do not belong to a given ('our') nation.

4 The research discussed by the author was carried out at the turn of 2017 and 2018; the obtained results were then verified and updated at the beginning of 2019. Among the analyzed websites, there were: I'm proud to be Polish (Pol. Jestem dumny, że jestem Polakiem); Lechistan of Patriots (Pol. Lechistan Patriotów); Young Patriots (Pol. Młodzi Patrioci); Patriots. Out of concern for my Homeland! (Pol. Patrioci. Z troski o Ojczyznę!); Patriotic Poland (Pol. Patriotyczna Polska); PATRIOTISM (Pol. PATRIOTYZM); Patriotism is in Poles (Pol. Patriotyzm jest w Polakach); Poland for the True Patriots (Pol. Polska dla Prawdziwych Patriotów); Patriotic education (Pol. Wychowanie patriotyczne) [names of websites in Polish are written in accordance with the source spelling]. 
It is also characterized by an attitude of contraculturation, negating, reluctant, and often opposing to external culture, threatening traditional culture (at the same time taking up nativistic actions focused on the preservation of traditional culture) (see: Bäcker, 2011: 139, 153-155).

Patriotism expressed in fake, lik eand hate looks for someone 'different', separate from 'us' - not only 'guilty' or 'worse', but also 'threatening,' 'wanting to destroy us'. Such an attitude corresponds to the characteristics of the phenomenon known as the besieged fortress syndrome, which involves arousing a sense of threat from a more or less imagined enemy and may lead to the abandonment of individualism for the sake of homogeneity of the group sensing the threat (Ziółkowski, 2014: 37-40; also: 2013: 117-131). Hence, patriotism expressed in fake, like and hate contains elements of populist, fundamentalist and nationalistic thinking: populist - in loving the people, in simple solutions to difficult problems and in supporting strong political power (personified in the form of a leader); nationalist - in referring to the motive of the benefits of one's nation (national egoism), in turn, as well as in invoking the power of tradition, original faith and morality of a given people (ethnic nationalism); fundamentalist - in unfavourable reactions to social, political and economic changes (see: Bäcker, 2011: 163-188).

More importantly, the observed phenomena should be considered as an expression of identity transformations. They can be regarded as the result of fatigue and dissatisfaction with the uniformity of values and behaviours within the European Union, the effect of searching for one's uniqueness (the uniqueness of one's community), the rejection of feeling ashamed for mistakes as an expression of weakness and submission, as well as the need to be an element of a proud, strong and unique community that is endowed with positive qualities, to deal with depravity, dangers and fear of the outside world (which appears to be hostile and dangerous). Patriotism expressed in fake, like and hate can therefore be interpreted as opposed to marginalization, exclusion and the need for success (see more: Adorno, 2010; Horney, 2009; Robins, Post, 2007). Such an expression of patriotism has its deep social roots, constituting a response to the needs, aspirations and fears of a human being faced with the inevitability of adaptation in a dynamically changing reality, which additionally operates in the conditions of constant necessity to implement democratic principles after the transition from the undemocratic system in Poland. This expression is strongly motivated by the shortage of victories in the Polish society, as the democracy built after 1989 was not deemed a success by everyone. The new behaviours, externalized in the Internet space, are in turn able to overcome this post-transition shortage of victories, and at least partially neutralize it (compare: Tischner, 2018).

To sum up, Polish patriotism, analyzed in the context of accounts defining themselves as patriotic on Facebook, firstly - showed its new face (shaped, on the one hand, by social needs, and technological progress, on the other), secondly - it is able (due to the still growing popularity of social media) to reach wider and wider audiences. The 
form of its message offers a great opportunity to influence the society, which makes it very dynamic. The memory of the past and patriotism are, therefore, not only variable phenomena, but also changing more and more intensively. This, in turn, leads to deepening the existing analyses in science and conducting almost continuous research on their phenomenon.

\section{Bibliography}

Adorno T.W. (2010), Osobowość autorytarna, Warszawa.

Assmann J. (2008), Pamięć kulturowa. Pismo, zapamiętywanie i polityczna tożsamość w cywilizacjach starożytnych, Warszawa.

Bäcker R. (2011), Nietradycyjna teoria polityki, Toruń.

Bartoletti R. (2011), Memory and Social Media: New Forms of Remembering and Forgetting, [in:] Learning from Memory: Body, Memory and Technology in a Globalizing World, edit. B.M. Pirani, Newcastle upon Tyne, pp. 82-111.

Bauman Z. (2000), Globalizacja, Warszawa.

Campbell J. (1997), Bohater o tysiącu twarzy, Poznań.

Caygill H. (1999), Meno and the Internet: between memory and the archive, "History of the Human Sciences", No. 12(1), pp. 1-11, DOI: https://doi.org/10.1177/095269519901200201.

Czeremski M., Sadowski J. (2012), Miti utopia, Kraków.

Delaperrière M. (2013), Miejsca pamięci czy pamięć miejsc? Kilka refleksji na temat uobecniania przeszłości w literaturze współczesnej, "Ruch Literacki”, Vol. LIV, No. 1(316), pp. 49-61, DOI: https://doi.org/10.2478/v10273-012-0054-7.

García-Gavilanes R., Mollgaard A., Tsvetkova M., Yasseri T. (2017), The memory remains: Understanding collective memory in the digital age, "Science Advances", No. 3(4), pp. 1-7, DOI: https://doi.org/10.1126/sciadv.1602368.

Ginosar A., Konovalov I. (2015), Patriotism on the internet: Journalists' behavior and user comments, “Media War \& Conflict", No. 8(3), pp. 368-383, DOI: https://doi.org/10.1177/1750635215607813.

Gündüz U. (2017), The Effect of Social Media on Identity Construction, "Mediterranean Journal of Social Sciences", No. 8(5), pp. 85-92, DOI: https://doi.org/10.1515/mjss-2017-0026.

Gündüz U., Erdem B.K. (2017), The concept of virtual nationalism in the digital age: Social media perspectives of Turkey, "Communication Today", No. 8(2), pp. 19-29.

Horney K. (2009), Neurotyczna osobowość naszych czasów, Poznań.

Jestem dumny, że jestem Polakiem,https://web.facebook.com/pg/PatriotyzmPolska/about/?ref=page_internal [access on: 17.04.2019].

Kołakowski L. (2005), Obecność mitu, Warszawa.

Lechistan Patriotów, https://www.facebook.com/groups/165174657168357/ [access on: 17.04.2019].

Leszkowicz T. (2017), 10 argumentów, że Imperium Lechitów nie istniało, https://histmag.org/10argumentow-ze-Imperium-Lechitow-nie-istnialo-TLDR-15840 [access on: 4.05.2019].

Marszałek-Kawa J., Ratke-Majewska A., Wawrzyński P. (2016), Polityka pamięci i kształtowanie tożsamości politycznej w czasie tranzycji postautorytarnej. Analiza porównawcza: Tom 2. Warszawa.

Maruszewski T. (2001), Psychologia poznania. Sposoby rozumienia siebie i świata, Gdańsk.

Minta-Tworzowska D. (2013), Pamięć, "miejsca pamięci” jako budujące tożsamość w ujęciu archeologii, "Przegląd Archeologiczny”, No. 61, pp. 33-50.

Młodzi Patrioci, https://www.facebook.com/patriocimlodzi/[access on: 17.04.2019]. 
Müller K., Schwarz C. (2018), Fanning the Flames of Hate: Social Media and Hate Crime, https:// warwick.ac.uk/fac/soc/economics/staff/crschwarz/fanning-flames-hate.pdf [access on: 23.04.2019].

Niepytalska-Osiecka A. (2014), O fejku, lajku i hejcie w polszczyźnie internetowej, "Język Polski”, No. 94(4), pp. 343-352.

Nora P. (2001), Czas pamięci, "Res Publica Nowa”, No. 7, pp. 37-43.

Patrioci. Z troski o Ojczyznę!, https://www.facebook.com/pg/InicjatywaPatrioci/about/?ref=page_internal [access on: 17.04.2019].

Patriotyczna Polska, https://web.facebook.com/pg/PatriotycznaPL/about/?ref=page_internal [access on:].

Patriotyzm jest w polakach, https://web.facebook.com/pg/BoPatriotyzmJestWPolakach/about/?re$\mathrm{f}=$ page_internal [access on: 17.04.2019].

PATRIOTYZM, https://web.facebook.com/pg/PATRIOTYZM-288614218005800/about/?ref=page_internal [access on: 17.04.2019].

Polska dla Prawdziwych Patriotów, https://www.facebook.com/groups/PolskaDlaPatriotow/ [access on: 17.04.2019].

Ratke-Majewska A. (2017), Obecność miejsc pamięci w przestrzeni publicznej jako narzędzie realizacji polityki pamięci w okresie potranzycyjnym. Chile i Hiszpania - wspólna droga?, [in:] ¿Adóndevas, España? Przemiany polityczne w Hiszpanii i Ameryce Łacińskiej na przełomie XX i XXI wieku, edit. S. Dudra, Ł. Młyńczyk, R. Michalak, Zielona Góra, pp. 45-73.

Ratke-Majewska A. (2018), Miejsce pamięci, [in:] Leksykon wiedzy politologicznej, edit. J. Marszałek-Kawa, D. Plecka, Toruń, pp. 269-274.

Ratke-Majewska A., Marszałek-Kawa J. (2017), The Politics of Memory and Political Identity: A Theoretical Overview, [in:] The Politics of Memory in Post-Authoritarian Transitions, Volume Two: Comparative Analysis, edit. J. Marszałek-Kawa, P. Wawrzyński, A. Ratke-Majewska (2017), Newcastle upon Tyne, pp. 31-74.

Robins R.S., Post J.M. (2007), Paranoja polityczna. Psychopatologia nienawiści, Warszawa.

Schacter D.L. (2003), Siedem grzechów pamięci. Jak zapominamy i zapamiętujemy, Warszawa.

Siewierska-Chmaj A. (2016), Mity w polityce. Funkcje i mechanizmy aktualizacji, Warszawa.

Szpociński A. (2008), Miejsca pamięci (lieux de mémoire), “Teksty Drugie”, No. 4, pp. 11-20.

Szpociński A. (2011), Pamięć przeszłości a formy przekazu, [in:] Pamięć w dobie internetu, edit. O. Kołakowska, R. Krajzewicz, M. Trepczyński, Warszawa, pp. 9-17.

Tischner J. (2018), Etyka solidarności oraz Homo sovieticus, Kraków.

Tokarz T. (2005), Problem subiektywizmu w konstruowaniu narracji historycznej, "Kultura i Historia", No. 8, pp. 4-11.

Traba R. (2006), Historia - przestrzeń dialogu, Warszawa.

Waniek D. (2011), Mity założycielskie - mity polityczne. Ich znaczenie w procesie kształtowania wspótczesnych podziałów społecznych, "Państwo i Społeczeństwo", No. 11(4), pp. 9-45.

Wychowanie patriotyczne, https://web.facebook.com/patriotyczne.wychowanie/ [access on: 17.04.2019].

Zimowska S. (2018), Z jakich mediów społecznościowych Polacy korzystają najchętniej?, https:// www.chip.pl/2018/07/z-jakich-mediow-spolecznosciowych-polacy-korzystaja-najchetniej/ [access on: 17.04.2019].

Ziółkowski J. (2013), Paradoksy syndromu oblężonej twierdzy w reżimach niedemokratycznych, [in:] Paradoksy polityki. T. 2, edit. J. Ziółkowski, Warszawa, pp. 117-131.

Ziółkowski J. (2014), O konsekwencjach społecznych "syndromu oblężonej twierdzy", "Dialog Edukacyjny: kwartalnik pedagogiczno-społeczny”, No. 4(27), pp. 37-40. 
Abstract: The purpose of the article is - firstly - to get an answer to the question of what image of Polish patriotism is offered by the Internet fake, like and hate, and secondly - to reflect on its causes and consequences for the Polish community. The text presents the results of the author's own research with comments and conclusions. The presented research relied, in turn, on the content analysis of the memory narratives constructed by users of Polish patriotic accounts functioning on Facebook. More importantly, the analyses focused on both formal issues (the number of sites and their popularity), as well as substantive ones (issues discussed within a given website, threads raised and users' opinions). Keywords: Internet social network, fake (Pol. fejk), like (Pol. lajk) and hate (Pol. hejt), memory, Polish patriotism

Article submitted: 1.07.2019; article accepted: 10.08.2019. 